\title{
Grammatical Gender: Acquisition, Attrition, and Change
}

\author{
Terje Lohndal \\ NTNU Norwegian University of Science and Technology/ \\ UiT The Arctic University of Norway \\ Marit Westergaard \\ UiT The Arctic University of Norway/ \\ NTNU Norwegian University of Science and Technology
}

This paper discusses grammatical gender in Norwegian by bringing together data from first language acquisition, Norwegian heritage language, and dialect change. In all these contexts, gender is often claimed to be a vulnerable category, arguably due to the relative nontransparency of gender assignment. Furthermore, the feminine gender is in the process of being lost in many Norwegian dialects, as feminine agreement forms (for example, the indefinite article) are merged with the masculine. The definite suffix, in contrast, is quite stable, as it is acquired early and does not undergo attrition/change. We argue that the combined data provide evidence that gender and declension class are separate phenomena, and we outline a possible formal analysis to account for the findings. ${ }^{*}$

Keywords: agreement, assignment, declension, feature, Norwegian, transparency

\footnotetext{
* We are grateful to a range of audiences who have provided feedback on various parts of the data discussed in this paper. In developing the analysis, we have especially benefitted from comments from Peter Svenonius and two anonymous reviewers. This research was supported by a grant from the Research Council of Norway for the project MiMS (Micro-variation in Multilingual Acquisition and Attrition Situations), project number 250857. The paper was completed during the international research project MultiGender at the Centre for Advanced Study at the Norwegian Academy of Science and Letters in Oslo during the academic year 2019-2020.

(C) Society for Germanic Linguistics 2021. This is an Open Access article, distributed under the terms of the Creative Commons Attribution license (http://creativecommons.org/licenses/by/4.0/), which permits unrestricted re-use, distribution, and reproduction in any medium, provided the original work is properly cited.
} 


\section{Introduction.}

What is grammatical gender? How is it acquired and how does it change in situations of language contact or reduced input and use? Finally, what can studies on the acquisition and attrition/change of gender tell us about this somewhat mysterious linguistic category? In this paper, we discuss recent research on acquisition and change of grammatical gender, with a focus on Norwegian varieties, and we make an attempt at tackling these fundamental questions.

Grammatical gender is acquired relatively late in Norwegian, due to the nontransparency of gender assignment (Rodina \& Westergaard 2013). A surprising finding in recent years is that feminine gender appears to be in the process of being lost in many dialects of Norwegian, including areas where the traditional three-gender system has been assumed to be quite stable in the spoken language, such as Tromsø (Rodina \& Westergaard 2015) and Trondheim (Busterud et al. 2019). Studies of Scandinavian heritage languages also show that the grammatical gender system is somewhat vulnerable in these populations (Heegård Petersen \& Kühl 2017 for Heritage Danish, Johannessen \& Larsson 2015 and Lohndal \& Westergaard 2016 for Heritage Norwegian). In the acquisition of gender in mono- and bilingual children, it is clear that there are some forms expressing gender distinctions that are in place much earlier than others. For example, the definite suffix is acquired several years before the indefinite article (see, among others, Rodina \& Westergaard 2013). A similar pattern between bound suffixes and free-standing forms is found in attrition and change, where certain forms are more vulnerable than others.

In our view, a key to understanding the gender category lies in identifying the cues that children are sensitive to in the acquisition process. In turn, these cues should create the foundation for a formal theory of grammatical gender. This paper argues that data from acquisition and attrition/change can inform such a formal theory. Certain morphosyntactic forms are stable across speakers and populations, whereas others are vulnerable and subject to change. We discuss why that is and what this says about the nature of grammatical gender.

The structure of the paper is as follows: In section 2, we discuss the organization of grammatical gender systems in Norwegian, and in section 3 we outline our theoretical assumptions and formulate the research questions. Section 4 provides an overview of grammatical 
gender in contexts of acquisition, attrition, and dialect change. Section 5 outlines a formal analysis, and section 6 is a brief conclusion.

\section{Grammatical Gender Systems in Norwegian.}

Norway is a country rife with dialectal variation (Haugen 1976, Vikør 1995): Every village essentially has its own dialect, and people mostly use their dialect in every aspect of life, making communication "polylectal" (Røyneland 2009:7). Traditionally, the three-gender system (masculine, feminine, neuter) has been preserved "in the overwhelming majority of the Scandinavian dialects down to the present" (Haugen 1976:288; setting aside the Bergen dialect as a well-known exception with a two-gender system of neuter and common (masculine + feminine) gender; see Jahr 1998, 2001 and Nesse 2005). The following table illustrates the ways in which gender is typically expressed in many dialects (excluding pronouns). Gender agreement is only expressed in the singular, but we also provide the plural indefinite and definite suffixes here.

\begin{tabular}{|c|c|c|c|}
\hline & Masculine & Feminine & Neuter \\
\hline Indefinite & $\begin{array}{l}\text { en hest 'a horse' } \\
\text { hesta(r) 'horses' }\end{array}$ & $\begin{array}{l}\text { ei seng 'a bed' } \\
\text { senge(r) 'beds' }\end{array}$ & $\begin{array}{l}\text { et hus 'a house' } \\
\text { hus-Ø 'houses' }\end{array}$ \\
\hline Definite & $\begin{array}{l}\text { hesten 'the horse' } \\
\operatorname{hestan}(\boldsymbol{e}) \text { 'the horses' }\end{array}$ & $\begin{array}{l}\operatorname{senga} \text { 'the bed' } \\
\operatorname{sengen}(\boldsymbol{e}) \text { 'the beds' }\end{array}$ & $\begin{array}{l}\text { huset 'the house' } \\
\text { husa(ne) 'the } \\
\text { houses' }\end{array}$ \\
\hline $\begin{array}{l}\text { Double } \\
\text { definite }\end{array}$ & $\begin{array}{l}\text { den hesten } \\
\text { 'that horse' }\end{array}$ & $\begin{array}{l}\text { den senga } \\
\text { 'that bed' }\end{array}$ & $\begin{array}{l}\text { det huset } \\
\text { 'that house' }\end{array}$ \\
\hline Adjective & $\begin{array}{l}\text { en fin hest } \\
\text { 'a nice horse' }\end{array}$ & $\begin{array}{l}\text { ei fin seng } \\
\text { 'a nice bed' }\end{array}$ & $\begin{array}{l}\text { et fint hus } \\
\text { 'a nice house' }\end{array}$ \\
\hline Possessive & $\begin{array}{l}\text { min hest/hesten min } \\
\text { 'my horse' }\end{array}$ & $\begin{array}{l}\text { mi seng/senga mi } \\
\text { 'my bed' }\end{array}$ & $\begin{array}{l}\text { mitt hus/huset mitt } \\
\text { 'my house' }\end{array}$ \\
\hline
\end{tabular}

Table 1. The traditional gender system in many varieties of Norwegian (idealized version based on a three-gender dialect).

There is considerable syncretism between masculine and feminine, for example, in the adjectives (setting aside the exceptional adjective

${ }^{1}$ The final consonant is silent in the neuter definite suffix. 
meaning 'little', which distinguishes all three genders, liten(M)-lita(F)lite $(\mathrm{N})$ ). Norwegian also displays double definiteness, which involves marking definiteness both with a suffix on the noun itself and on a prenominal determiner in contexts where the noun is preceded by a demonstrative or modified, for example, by an adjective. In this case, there is also syncretism between the masculine and the feminine for the prenominal markers, with den being the common form and det being the neuter. The same applies to demonstratives and certain quantifiers, not illustrated in the table: denne bilen $(\mathrm{M})$ 'this car', denne boka(F) 'this book', and dette huset( $\mathrm{N})$ 'this house' for demonstratives, and all maten(M) 'all the food', all suppa(F) 'all the soup', alt $\operatorname{rotet}(\mathrm{N})$ 'all the mess' for quantifiers.

Some traditional Norwegian dialects have a system whereby each gender has two different definite suffixes. Table 2 provides a typical example from the dialect of Oppdal (Haugen 1982:69-78).

\begin{tabular}{|l|l|l|l|}
\hline Gender & Class & Indefinite & Definite \\
\hline \multirow{2}{*}{ Masculine } & strong & gut 'boy' & guten 'the boy' \\
\cline { 2 - 4 } & weak & beng 'container' & bengin 'the container' \\
\hline \multirow{2}{*}{ Feminine } & strong & myr 'swamp' & myra 'the swamp' \\
\cline { 2 - 4 } & weak & fluggu 'fly' & floggo 'the fly' \\
\hline \multirow{2}{*}{ Neuter } & strong & hus 'house' & huset 'the house' \\
\cline { 2 - 4 } & weak & jart 'heart' & jarta 'the heart' \\
\hline
\end{tabular}

Table 2. Examples of inflectional forms in the dialect of Oppdal.

As the table shows, each of the three genders can be divided into two classes, often labeled strong and weak in the Germanic literature. There is also syncretism across some of the classes, for example, the strong feminines and the weak neuters have the same ending in the Oppdal dialect. It should be noted that table 2 is grossly simplified, as there are far more subclasses for each of the three genders if all patterns in the Oppdal dialect are taken into consideration (see Haugen 1982). There is also considerable variation in the morphosyntactic realization of gender and declension class across Norwegian dialects, as demonstrated in great detail by Skjekkeland (1997), but which we cannot cover here. 
The classes in table 2 are often referred to as declension classes or inflection classes. These are often defined as groups of lexemes sharing a set of "inflectionally realised morphosyntactic properties" and "the inflectional markers" that realize them (Carstairs-McCarthy 2000:630). As Aronoff (1994:66) puts it, an inflection class is "a set of lexemes whose members each select the same set of inflectional morphemes." Further discussion of the relationship between declension class and gender may be found in Alexiadou 2004 and Vadella 2016.

Gender assignment in Norwegian is relatively nontransparent, in that there are very few, if any, reliable gender cues on the noun itself, unlike, for example, in Russian or Italian, where the morphophonological shape of a noun generally predicts its gender. Nevertheless, Trosterud (2001) has proposed as many as 43 different rules for gender assignment in Norwegian, comprising phonological, morphological, and semantic rules, as well as a masculine default. Unfortunately, most of these rules have a considerable number of exceptions, and some are quite specific (for example, words denoting buildings that are not used as permanent housing for humans are neuter), and it seems somewhat unlikely that learners of the language would acquire such rules or (semi-)regularities from input only. In an experiment using nonce words, Gagliardi (2012) also shows that Norwegian children are not sensitive to the two cues argued to be the most reliable ones in Norwegian, the ending $-e$ and reference to a female individual, both typical of feminine nouns, as in $e i$ skjorte 'a shirt', ei søster 'a sister'. This does not necessarily mean that gender assignment in Norwegian is completely arbitrary. For example, Bobrova (2013) shows that Norwegian adults relatively reliably distinguish between neuter and common (masculine + feminine) gender based on the animacy of a nonce word. However, what one ideally would like to see is how speakers perform on a set of nonce words that all refer to inanimates. This is investigated in ongoing work (Urek et al. 2018), and the findings suggest that there may be certain phonological patterns that adult speakers of Norwegian are (somewhat) sensitive to.

In a non-transparent system, frequency is important, and there is a considerable difference between the three genders in this respect, with the masculine being by far the most frequent gender. Based on the 31,500 nouns in the Nynorsk Dictionary, Trosterud (2001) has found that $52 \%$ of all nouns are masculine, $32 \%$ are feminine, and only $16 \%$ are neuter. In everyday use, the masculine is even more frequent: Rodina \& 
Westergaard (2015) investigated samples of child-directed speech and found that token frequencies of masculine nouns make up as much as $62.6 \%$ of the input, while feminine and neuter nouns account for $18.9 \%$ and $18.5 \%$, respectively.

Ongoing work suggests that there may be semantic as well as phonological cues or tendencies for gender assignment in Norwegian that speakers are to some extent sensitive to (Urek et al. 2018). For example, in a reading-based elicitation experiment where Norwegian native speakers had to read out nonce nouns and add an appropriate indefinite article, Urek et al. (2018) find that, although the masculine is clearly favored in all contexts, there is a statistically significant effect of certain final segments, with /-e/ often being linked to feminine gender and /-v/ to neuter. When the same nonce words are presented in an experiment with pictures (of novel inanimate objects), all participants produce exclusively masculine, suggesting that either semantics or the explicit instruction to add a gendered article may also play a role. However, further experiments are needed to better understand to what extent gender assignment in Norwegian is arbitrary or not.

Finally, we would like to mention gender assignment to loan words: Graedler (1998) and Johansson \& Graedler (2002) consider gender assignment to English borrowings in contemporary Norwegian based on corpus data. They find that $80-90 \%$ of the nouns are masculine, $10-20 \%$ are neuter, and very few are feminine (Johansson \& Graedler 2002:183). A considerable number of loanwords also fluctuate between masculine and neuter. Nevertheless, there are tendencies for certain endings on English nouns to correspond to a specific gender. For example, English loan words ending in -ing or -er are typically masculine in Norwegian, whereas monosyllabic nouns are typically neuter.

\section{Theoretical Assumptions and Research Questions.}

The previous section illustrates the complexity of the Norwegian gender and nominal declension system. In this section, we discuss some relevant theoretical proposals and issues concerning grammatical gender and declension class before we present our research questions for this paper.

In the study of grammatical gender in Norwegian, a notoriously contested issue revolves around the definite suffix. This morpheme typically differs across the three genders, which has led scholars to analyze it as a real gender marker. For example, traditional Norwegian 
grammars (such as Faarlund et al. 1997) consider the definite suffix to be an exponent of gender (see also Andersson 2000 and Dahl 2000 for a similar conclusion for Swedish). On the other hand, applying the definition given by Hockett (1958), which states that "[g]enders are classes of nouns reflected in the behavior of associated words" (see also Corbett 1991), this suffix should not be considered to be an exponent of gender, but rather a declension class marker, as argued in Fretheim 1985, Lødrup 2011, Rodina \& Westergaard 2015, Lohndal \& Westergaard 2016, Svenonius 2017, and Busterud et al. 2019. An in-between position is pursued by Enger (2004a:137), who argues that the suffix encodes gender to a certain degree (see also Berg 2019). Whether or not the definite suffix is an expression of gender or declension class also depends on what the relationship between gender and declension is in varieties of Norwegian, that is, whether gender can predict declension class or vice versa (see, in particular, Enger 2004a).

From a crosslinguistic point of view, there is wide agreement that gender and declension class are distinct phenomena (see, among others, Roca 1989; Harris 1991, 1996; Halle 1992; Aronoff 1994; Comrie 1999; Thornton 2001; Wechsler \& Zlatić 2003; Alexiadou 2004; Kramer 2015; Svenonius 2017). Formal approaches have developed different ways of capturing this distinction. For reasons of space, we only illustrate one approach here (see Kramer 2016 for an overview), which is couched within the theory of Distributed Morphology (DM). This approach argues that word formation consists of category-less roots that have to merge with elements of the functional vocabulary in order to form larger units (Marantz 1997; Alexiadou 2001; Arad 2003, 2005; Embick \& Marantz 2008; Embick 2015; De Belder 2011; Alexiadou \& Lohndal 2017). For example, a root merges with a $v$ to form a verb, and similarly, a root merges with an $n$ to form a noun, as illustrated in 1 .
(1) a. $[\mathrm{v} v \sqrt{ } \mathrm{ROOT}]$
b. $[\mathrm{n} n \sqrt{ }$ ROOT $]$

A root has to be merged to ensure that a category is assigned, which Embick \& Marantz (2008:6) label the categorization requirement. Kramer (2015) argues that $n$ is the locus of gender assignment, and she develops a comprehensive approach to gender within DM. 
Next, let us consider how to account for declension class, given its importance for the analysis of grammatical gender in Norwegian. It is typically argued that declension class features play no role in syntax (see, among others, Harris 1991, 1996; Aronoff 1994; Oltra-Massuet 1999; Alexiadou 2004; Embick \& Halle 2005; Oltra-Massuet \& Arregi 2005; Alexiadou \& Müller 2008; Kramer 2015). This means that declension class features do not take part in syntactic operations such as, for example, agreement. For this reason, much work within the framework of DM argues that declension class information is inserted after syntax proper, in what DM labels the morphological component; that is, postsyntactically (see, among others, Embick \& Halle 2005, Kihm 2005, Halle \& Matushansky 2006, Steriopolo 2008, Embick 2010, Alexiadou 2011, Kramer 2015, Vadella 2016; see also Svenonius 2017 for a somewhat different theoretical approach to some of the Norwegian data).

Space prevents us from going into the technical implementation in detail, but Kramer (2015) argues that the declension class feature adjoins to the categorizing head, which is to say that $2 \mathrm{a}$ turns into $2 \mathrm{~b}$ in the postsyntactic component (Vadella 2016, pace Alexiadou \& Müller 2008).

(2)

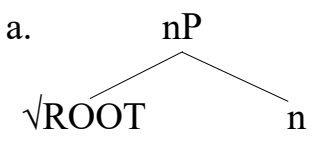

b.

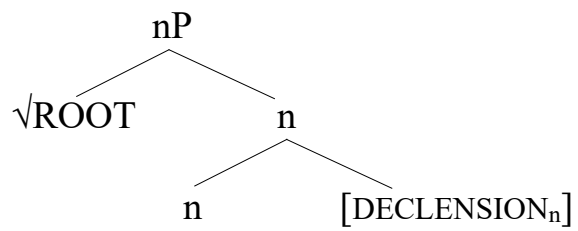

Kramer (2015:239) argues that for Spanish, this approach would require that roots are specified for which declension class they take. Kramer (2015:238-239) discusses various ways in which this can be achieved technically, which in part depends on whether or not roots are allowed to carry declension class features. Since this is not important for present purposes, we set the specific choice of implementation aside here.

Given the empirical and theoretical landscape discussed above, several questions emerge, and in this paper we discuss the following:

(i) How is grammatical gender acquired across varieties of Norwegian?

(ii) How does grammatical gender change in Norwegian heritage language? 
(iii) How does grammatical gender change across varieties of Norwegian?

(iv) How can one formalize grammatical gender in varieties of Norwegian and how could a formal model account for the answers to research questions $\mathrm{i}-\mathrm{iii}$ ?

Section 4 provides answers to questions i-iii, whereas section 5 outlines a formal analysis based on DM. This analysis captures the observed generalizations regarding grammatical gender in Norwegian, including the distinction between grammatical gender and declension class.

\section{Gender Systems in Development: Stable Versus Vulnerable Cues.}

In this section, we address questions $\mathrm{i}$-iii by providing a synopsis of recent studies on grammatical gender in Norwegian. Space does not allow us to go into great detail for each of the studies mentioned; rather, we attempt to summarize and extract generalizations across the following three domains: Acquisition, attrition, and dialect change.

\subsection{Acquisition.}

Given the non-transparent nature of grammatical gender in Norwegian, one might expect delayed acquisition compared to other languages with more predictable gender assignment. Indeed, this turns out to be the case: Rodina \& Westergaard (2015) provide experimental evidence that targetconsistent gender assignment (of neuter gender) is not in place until approximately age 7 (with $90 \%$ accuracy). This is considerably later than in languages with more transparent gender assignment, for example, Russian or Italian (Kupisch et al. 2002, Rodina 2008).

The nontarget-consistent production attested in child data generally involves overgeneralization of masculine gender, argued to be the default in Norwegian and clearly the most frequently occurring gender in children's input (see section 2). Occasional examples of this overuse of the masculine, affecting both feminine and neuter gender, are provided in Plunkett \& Strömquist 1992 and Anderssen 2006. A more systematic analysis is found in Rodina \& Westergaard 2013, where corpora of two monolingual and two bilingual Norwegian-English children (Anderssen 2006, Bentzen 2000) were investigated. Their findings show that, although there is some variation across the four children and also across the different gender forms (for example, determiners, adjectives, and 
possessives), both the feminine and the neuter gender are affected to a considerable extent: For example, the feminine and neuter indefinite articles $e i$ and et are replaced by the masculine form en 63\% (69/109) and $71 \%(89 / 126)$ of the time, respectively, as illustrated in 3 . Masculine gender, in contrast, is generally unproblematic, with only $1 \%$ nontarget forms $(2 / 272){ }^{2}$

(3) a. en mus (Emma 2;7.21)

a.M mouse. $F$

Target: ei(F) mus

b. en hode (Ina 2;10.2)

a.M head.N

Target: et $(\mathrm{N})$ hode

These results differ from findings in languages with more transparent gender, where young children are found to overgeneralize a specific assignment rule rather than resorting to the default. For example, Russian children overgeneralize feminine gender to exceptional masculine nouns ending in $-a$, which is a typical feminine ending belonging to declension II (see, among others, Rodina \& Westergaard 2012). ${ }^{3}$

(4) deduška oranževaja na tareločke (Vera 3;9)

granddad(II) orange.F on plate

'The orange granddad is on the plate.'

Target structure: deduška oranževyj(M) na tareločke

One consistent finding in the literature on the acquisition of Norwegian noun phrases is that there is a clear distinction between the definite and plural suffixes on the one hand and forms that show gender

2 Such overgeneralization patterns, indicating that there are no gender distinctions in child language at a very early stage, have also been attested for German child language (see, among others, Müller 1999, Eichler et al. 2013).

${ }^{3}$ Russian has three genders, but four declension classes, where nouns in declension class I are masculine, nouns in declensions II and III are feminine, and nouns in declension IV are neuter (see Corbett 1991, among others). 
agreement with the noun on the other (the latter being true exponents of gender, according to Hockett's 1958 definition). In Rodina \& Westergaard's (2013) study mentioned above, the findings based on the corpus data of the four children show that, while gender marking on determiners, adjectives, and possessives is highly problematic, the definite and plural suffixes are generally in place with the targetconsistent form from early on: For the definite suffix, for example, the overgeneralization of the masculine -en ending to feminine and neuter nouns is only $4 \%$ for both genders (3/138 and 10/229, respectively). ${ }^{4}$ This is in stark contrast to the nontarget-consistent production of gender forms on other targets, as illustrated for the indefinite article in $3(63 \%$ and $71 \%$ ). Similar findings are attested in experimental work (see, for instance, Rodina \& Westergaard 2015, 2017 and Busterud et al. 2019).

\subsection{Attrition.}

In recent years, there has been some focus on Scandinavian languages as heritage languages, especially in North America. A heritage language is a language that is "spoken at home or otherwise readily available to young children, and crucially this language is not a dominant language of the larger (national) society" (Rothman 2009:156). Heritage speakers are simultaneous or successive bilinguals, and they often undergo a dominance shift around the age when they start school, from being dominant in the heritage language to becoming dominant in the majority language. In this process, their L1 may attrite as a result of reduced input and use, and, consequently, the language of adult heritage speakers is often somewhat different from the nonheritage variety (or the input that they received as children). ${ }^{5}$

Grammatical gender in Norwegian heritage language in the USA and Canada has been investigated by a number of scholars, most notably Johannessen \& Larson (2015) and Lohndal \& Westergaard (2016). While

\footnotetext{
${ }^{4}$ The proportion of nontarget-consistent production of suffixes for all three genders is as follows: Definite singular 2\% (17/851), indefinite plural $4 \%$ $(8 / 212)$, and definite plural 6\% (10/161).

${ }^{5}$ An important question in heritage language research-which we do not address here - is whether these differences are due to attrition or arrested development. The latter is often referred to as incomplete or differential acquisition (Montrul 2008, Kupisch \& Rothman 2016).
} 
they to some extent study the same data (the CANS corpus of elderly speakers who are mainly 3rd generation immigrants; Johannessen 2015), they come to somewhat different conclusions: While Johannessen \& Larsson (2015) claim that the gender system is relatively stable, Lohndal \& Westergaard (2016) argue that grammatical gender is vulnerable. Coming back to the issue of definition raised in section 3, this discrepancy can mainly be explained as a result of different views on the definition of gender: While Johannessen \& Larson (2015) follow the tradition in the study of Norwegian grammar, where the suffixes are considered to be gender markers, Lohndal \& Westergaard (2016) assume the standard definition of gender in Hockett 1958 and Corbett 1991.

The reason why the choice of definition makes such a difference is that it determines the interpretation of the findings, which are essentially the same in both studies and correspond to what is found in child language data (see section 4.1): Most of the heritage speakers produce a high number of gender forms that deviate from the nonheritage variety. For example, according to Lohndal \& Westergaard (2016), who studied 50 speakers in the CANS corpus, masculine gender is overgeneralized to feminine nouns $39 \%(92 / 236)$ and to neuter nouns as often as $48.8 \%$ $(80 / 164)$ of the time. Examples are shown in 5: The masculine indefinite article is used with a feminine and a neuter noun in $5 \mathrm{a}$ and $5 \mathrm{~b}$, respectively. Crucially, however, the definite suffixes are virtually always retained with the baseline form.

$$
\begin{aligned}
& \text { a. en datter } \quad \text { datter-a } \\
& \text { a.M daughter(F) daughter(F)-DEF.F }
\end{aligned}
$$

b. en år

—år-et

a.M year(N)

$$
\text { year(N)-DEF.N }
$$

Now, assuming that the definite suffix is an exponent of gender (see Johannessen \& Larsson 2015), the data in 5 indicate that the gender system itself is intact. In contrast, assuming that the definite suffix only marks declension class (see Lohndal \& Westergaard 2016), the conclusion is drawn based on the use of the indefinite article alone, and the same data suggest that gender is highly affected by attrition.

At first glance, Johannessen \& Larsson's analysis should be preferred: Most of the heritage speakers have an intact gender system, in 
that they use all three gender forms; they simply do not use them with the right nouns. That is, it is gender assignment that is vulnerable, which is not surprising given the non-transparency of the system. Furthermore, no speakers have a reduced gender system (of two genders instead of three), which has been attested for Russian heritage language (Polinsky 2008). These observations may suggest that the gender system itself is intact, and it is only gender assignment that is vulnerable. Note, however, that a small subset of the speakers (9 individuals) seem to have no gender system at all, in that they only produce masculine forms (for nouns of all genders). Lohndal \& Westergaard (2016) therefore argue that attrition of grammatical gender involves general erosion of gender assignment, which may eventually lead to a complete loss of gender distinctions. ${ }^{6}$

\subsection{Dialect Change.}

Many languages in the Germanic family have undergone changes in their grammatical gender systems, either a reduction from three to two genders (Dutch, Swedish, and Danish) or the complete loss of gender (English). ${ }^{7}$ As mentioned in section 1, Norwegian dialects have traditionally retained a stable three-gender system, with the notable exception of the Bergen dialect, which changed into a two-gender system due to language contact with low German during the Hansa period (for

${ }^{6}$ Several scholars have considered the gender of English loan words in Norwegian heritage language (Flom 1903, Haugen 1953, Grimstad et al. 2018, Riksem 2018). Haugen (1953) argues that there are some cues determining the assignment of gender to English nouns, though recent evidence from the CANS corpus suggests that there is more variability than previously assumed (Lohndal 2018, Riksem 2018).

${ }^{7}$ Notably, we set aside pronominal gender. Traditionally, pronominals agreed in gender with both animates and inanimates; but this system has disappeared in many dialects, and now gender agreement is only retained with animate nouns (see Enger 2004b, 2011 for some discussion). While there is no research on this, it is our clear impression that this change predates the ongoing change in the gender system in Tromsø and Trondheim, suggesting that the current change does not simply involve an analogical extension of an already existing set of formal identities between masculine and feminine. New evidence from possessives also shows a collapse of masculine and feminine that aligns with the findings summarized in the present paper (see Rodina \& Westergaard, forthcoming). 
example, Jahr 1998, 2001). Historically, it is known that the degree of correlation between gender and declension varies across Germanic languages (Kürschner \& Nübling 2011), and there has been a diachronic tendency to align gender and declension in West Nordic (Bjorvand 1972, Enger 2004a, Berg 2019).

In addition to the Bergen dialect, other contact varieties of Norwegian have also lost the feminine gender. This has taken place in dialects spoken in Northern Troms, where Norwegian has been in extensive contact with Saami and Kven (a variety of Finnish; Conzett et al. 2011). Furthermore, urban ethnolects spoken in Norway have been shown to display a gender system without the feminine (Opsahl 2009). In both cases, nouns which previously displayed feminine agreement are now used with masculine agreement, which means that the new gender system has two genders, common (masculine + feminine) and neuter. Interestingly, the declensional suffixes are typically not affected by this change. Thus, while the feminine indefinite article $e i$ is replaced by masculine en, the definite suffix is retained, resulting in the following pattern, which is also found in child language and heritage language data (see sections 4.1 and 4.2):

(6) a. en bok - bok-a

$$
\text { a.C } \operatorname{book}(\mathbf{F}) \quad \operatorname{book}(\mathbf{F})-\mathrm{DEF} . \mathbf{F}
$$

b. en prinsesse - prinsess-a

a.C $\operatorname{princess}(\mathbf{F}) \quad$ princess $(\mathbf{F})-\mathrm{DEF} . \mathbf{F}$

Recent studies indicate that this change is occurring also in other Norwegian dialects. Investigating a corpus of Oslo speech, Lødrup (2011) shows that the feminine gender is more or less lost among speakers in the capital, with older speakers using feminine forms very rarely and young speakers hardly at all. A similar development has been attested in Tromsø, in the north of Norway. Rodina \& Westergaard (2015) carried out an experimental study with five age groups, showing that the feminine gender forms are rapidly losing ground: The feminine indefinite article $e i$ is attested only between $7 \%$ and $15 \%$ of the time among three age groups of children, while adults (age 30 and above) use this form virtually $100 \%$ of the time, and teenagers are in the middle with $56 \%$ feminine forms. The same study has recently been carried out in 
Trondheim, a larger city in the middle of the country. The results show that the development toward a two-gender system is even more advanced there, with the youngest children producing the feminine form ei only $4 \%$ and adults as little as $35 \%$ of the time (Busterud et al. 2019). In both locations, the definite suffix is virtually unaffected, however, leading to a system similar to that illustrated in $6 .^{8}$ This means that there is a simplification in the gender system, but a corresponding addition of complexity in the declension system, in that the new common gender now has two classes, the -en class and the $-a$ class (corresponding to previously masculine and feminine nouns, respectively).

Lundquist et al. (2016) use a Visual World Paradigm experiment to study noun anticipation effects triggered by the three gender forms of the indefinite article in two dialects in Northern Norway: Tromsø and Sortland (see also Lundquist \& Vangsnes 2018 on yet a different dialect combination). This paradigm is ideally suited for studying how speakers make use of the gender form of an article to predict an upcoming target noun, and it has been widely applied to the study of grammatical gender (for example, Dahan et al. 2000, Dussias et al. 2013, Hopp 2016). Lundquist et al. (2016) find that even though the Sortland speakers still make a three-way gender distinction in their production, they do not seem to use gender cues (that is, gender forms of the indefinite article) to anticipate feminine or masculine nouns. This is different for speakers of a (stable) two-gender dialect (the Tromsø speakers), who use the masculine as a predictive cue. Neuter is a predictive cue for speakers of both dialects. Based on these findings, Lundquist et al. (2016) argue that in a context of language change (exemplified by the Sortland dialect), comprehension is affected before production.

Many factors have been suggested as the cause of the loss of feminine gender. Sociolinguistic factors are commonly used to explain the current development, focusing on what has been referred to as "educated casual style" (Torp 2005:1428), a conservative variety of Bokmål, which has recently come to be considered a "posh" way of

\footnotetext{
${ }^{8}$ As Busterud et al. (2019) point out, in the youngest speakers in Trondheim there is a slight tendency for the definite suffix also to be affected, which leads to a collapse of masculine and feminine in the declension system as well. More research is necessary to determine whether this tendency is indicative of an incipient change or not.
} 
speaking in urban areas. As this style typically uses a two-gender system (that is, common and neuter), feminine forms are increasingly considered old-fashioned, rural, and "uncool" (Rodina \& Westergaard 2015, Busterud et al. 2019, Opsahl, this issue). However, some linguistic factors are also at play: Simplification is a common result of L2 acquisition and language contact, especially in morphology (see, in particular, Trudgill 2013). Furthermore, the considerable syncretism between the masculine and the feminine makes it difficult to distinguish the feminine forms in acquisition (as the masculine forms are massively more frequent). Finally, the loss of the true gender forms and the retention of declensional suffixes has been related to the fact that the latter are acquired early (around the age of two), while the former are typically not target-consistent in place until age 6-7 (Rodina \& Westergaard 2013, 2015). It is a generally accepted view that forms that are acquired early should be stable, while late-acquired properties are more vulnerable to change.

To summarize the discussion of stable versus vulnerable cues, across the different scenarios of acquisition, attrition, and dialect change, the following generalizations emerge: i) Feminine gender is subsumed by masculine in acquisition and attrition, and is thus also subject to diachronic change; ii) Even though it is acquired relatively late, neuter gender is stable; and iii) Free-standing gender forms develop differently from suffixes, in that the latter are acquired early and do not undergo change. In section 3, we asked how grammatical gender in varieties of Norwegian could be formalized in order to account for the findings from acquisition, attrition, and change (question iv). In the next section, we address this question and consider one way to account for these generalizations.

\section{Toward a Formal Analysis.}

Given the data reviewed in section 4 together with the theoretical background in section 3, we now try to develop a formal analysis that can account for the findings. Let us first outline what this analysis should capture:

(7) a. Feminine gender is lost in many dialects. Morphologically it merges with the masculine form. 
b. Feminine gender disappears, but the definite suffix does not change.

c. New nouns generally become masculine.

d. In a dialect, where the gender system is undergoing change, neither masculine nor feminine gender is predictive, only neuter gender is.

e. Neuter gender is unaffected by the disappearance of feminine gender.

f. Neuter gender is default agreement, for example, on postcopular adjectives with sentential subjects.

The facts behind $7 \mathrm{a}-\mathrm{e}$ have been discussed above, while $7 \mathrm{f}$ refers to data such as 8 .

(8) [At Marie kommer på konserten,] er spesielt. ${ }^{9}$ that Marie comes on concert.DEF is special.N 'That Marie comes to the concert is unusual.'

Sentential subjects do not have any gender features, yet the agreement on the postcopular adjective is neuter (across all dialects) and not the common form. This suggests that neuter is the default agreement gender in Norwegian, that is, the gender that shows up in the absence of any gender cues ("neutral agreement" in the words of Corbett \& Fraser 1999). In contrast, default gender assignment in Norwegian is clearly masculine. Thus, one needs to distinguish between different types of defaults in Norwegian: An agreement default (neuter) and an assignment default (masculine; see Corbett \& Fraser 1999, Enger 2009).

How can one formalize the Norwegian gender systems in a way that also captures the directionality of the ongoing change? Using formal features, a range of options exist; space does not allow us to consider all of them and the question of whether or not the difference is notational or substantial. A core element in the analysis concerns the choice of the

\footnotetext{
${ }^{9}$ Spesiell is the common form, so -lt displays the agreement. However, there is a lot of controversy regarding the division of morphemes, so we decided not to take a stance and simply mark the form as neuter.
} 
default. Here our attention is limited to the syntactic default, neuter. ${ }^{10} \mathrm{We}$ are also assuming that features can be multivalued, acknowledging that there are a range of issues facing the choice of feature ontology (see Corbett 2012 and Bank 2014). Our proposal, then, involves the features in 9, which would be located on the categorizer $n$ within a DM analysis (compare Kramer 2015). An empty feature matrix for neuter means that it is the default, or underspecified gender. ${ }^{11}$

(9) a. [GEN: MASC]

b. [GEN: FEM]

masculine

c. []

feminine

neuter

Turning to two-gender dialects, we argue that in these varieties, [GEN: FEM] has been lost, which forces a reanalysis of masculine gender, resulting in the following feature system:
(10) a. [GEN: COMMON]
b. []
common
neuter

Neuter has the same feature representation in both gender systems, since it is completely unaffected by the change.

Next, we consider the definite suffix and its relation to free morphemes (that is, true gender forms, according to Hockett 1958 and Corbett 1991). In section 3, we showed that the definite suffix in Norwegian has a controversial status, some arguing that, although it is an element that is attached to the noun and therefore does not agree with it,

\footnotetext{
${ }^{10}$ As Johansson \& Graedler (2002) make clear, many different factors play a role when it comes to gender assignment to loan words, and independent mechanisms are therefore needed to account for which gender category new words go into.

${ }^{11}$ See Opitz \& Pechmann (2016) for underspecification in German. Note that, morphologically speaking, neuter could be considered the most marked gender in the sense that it has the least syncretic forms compared to masculine and feminine (or common in two-gender dialects). We are not committed to a specific notion of underspecification or markedness per se. As Haspelmath (2006) makes clear, these terms have been used in a range of different senses in the literature. See his paper for a critical discussion.
} 
it is nevertheless an exponent of gender. In section 4, we reviewed data from acquisition, attrition, and change showing the difference between gender agreement on other words (for example, the indefinite article) and suffixes (expressing number and definiteness). Like Rodina \& Westergaard (2015) and Lohndal \& Westergaard (2016), we interpret these findings as evidence that the suffixes are different from true gender markers. More specifically, we develop an analysis whereby the definite suffix is considered a marker of declension class (see discussion in section 4.2). Typically, a dialect with the new two-gender system, as in 10 , would have the declension classes and exponents in the singular definite shown in 11 .

(11) a. Declension class I: -en (for example, bil-en 'car-DEF')

b. Declension class II: - $a$ (for example, bok-a 'book-DEF')

c. Declension class III: -et (for example, hus-et 'house-DEF')

In many three-gender dialects (with the exception of dialects such as Oppdal, see table 2), there is a one-to-one correspondence between declension and gender: Classes I, II, and III correspond to masculine, feminine, and neuter, respectively, raising the question whether gender predicts declension class or declension class predicts gender (Enger 2004a, Berg 2019). In a two-gender system with only common and neuter gender, there is a less transparent relationship between gender and declension class, in that common gender consists of two declension classes (I and II). Neuter declension class can then be treated as the elsewhere case, on a par with our analysis of neuter gender. Following Kramer's (2015) analysis outlined in section 3, a previously feminine noun phrase such as en bok 'a book' would then have the following analysis:
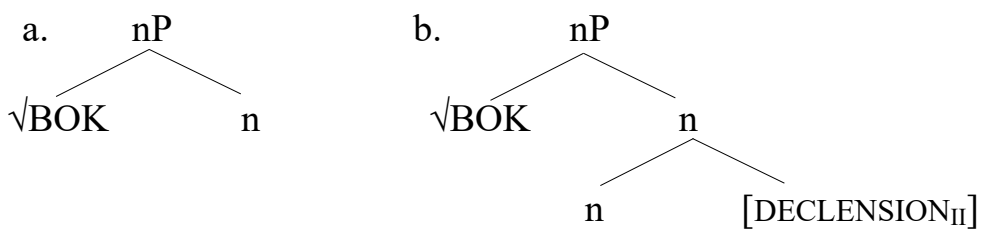

Example $12 \mathrm{a}$ is the narrow syntactic structure, whereas $12 \mathrm{~b}$ is the structure after the declension class feature adjoins to the categorizing 
head in the postsyntactic component. The spell-out of $12 \mathrm{a}$ is boka, the relevant form in many dialects.

\section{Conclusion.}

In this paper, we have discussed aspects of the grammatical gender system in varieties of Norwegian, relying on evidence from acquisition, attrition, and dialect change. We have identified a common pattern: The feminine gender is vulnerable, which is clearly seen in the disappearance of the indefinite article. The definite suffix, however, is not problematic: It is acquired early and shows no signs of either attrition or change. We have proposed an outline of a formal analysis that can capture the transition from a three- to a two-gender system in Norwegian, both for gender markers proper and for declension class markers.

Previous research is divided in terms of whether there are predictive cues for gender assignment in varieties of Norwegian. However, most of this work only considers gender assignment based on Norwegian words. As emphasized by Corbett (1991), Thornton (2009), and Audring (2016), among others, it is necessary to investigate gender assignment to loan words and nonce words to "uncover psychologically real and productive criteria that speakers exploit in 'on-the-spot' gender assignment" (Thornton 2009:17) rather than appeal to what Comrie (1999:461) has labeled "postfactum rationalizations," which often characterize some of the gender assignment generalizations proposed in the literature. As discussed in section 2, the picture for Norwegian is rather unclear when it comes to the nature of gender assignment. Much more research is needed in order to uncover the subtle cues and tendencies that speakers seem to be sensitive to.

\section{REFERENCES}

Alexiadou, Artemis. 2001. Functional structure in nominals. Amsterdam: John Benjamins.

Alexiadou, Artemis. 2004. Inflection class, gender and DP-internal structure. Explorations in nominal inflection, ed by Gereon Müller, Lutz Gunkel, \& Gisela Zifonun, 21-50. Berlin: Mouton de Gruyter.

Alexiadou, Artemis. 2011. Aspectual properties of nominalization structures. Morphology and its interfaces, ed. by George Tsoulas, Glyn Hicks, \& Alexandra Galani, 195-220. Amsterdam: John Benjamins. 
Alexiadou, Artemis, \& Terje Lohndal. 2017. The structural configurations of root categorization. Labels and roots, ed. by Leah Bauke \& Andreas Blümel, 101-155. Oxford: Oxford University Press.

Alexiadou, Artemis, \& Gereon Müller. 2008. Class features as probes. Inflectional identity, ed. by Asaf Bachrach \& Andrew Nevins, 101-155. Oxford: Oxford University Press.

Anderssen, Merete. 2006. The acquisition of compositional definiteness in Norwegian. Tromsø, Norway: University of Tromsø dissertation.

Andersson, Erik. 2000. How many gender categories are there in Swedish? Gender in grammar and cognition II: Manifestations of gender, ed. by Barbara Unterbeck, Matti Rissanen, Terttu Nevalainen, \& Mirja Saari, 545560. Berlin: Mouton de Gruyter.

Arad, Maya. 2003. Locality constraints on the interpretation of roots: The case of Hebrew denominal verbs. Natural Language and Linguistic Theory 21. 737-778.

Arad, Maya. 2005. Roots and patterns: Hebrew morpho-syntax. Dordrecht: Springer.

Aronoff, Mark. 1994. Morphology by itself. Cambridge, MA: MIT Press.

Audring, Jenny. 2016. Gender. Oxford research encyclopedia in linguistics. https://dx.doi.org/10.1093/acrefore/9780199384655.013.43, July 2016.

Bank, Sebastian. 2014. The algebraic structure of morphosyntactic features. Nordlyd 41. 239-259.

Bentzen, Kristine. 2000. I like not it like du like it! A case study of language transfer in bilingual first language acquisition. Tromsø, Norway: University of Tromsø M.Phil. thesis.

Berg, Ivar. 2019. Gender and declension mismatches in West Nordic. Historical Linguistics 2015: Selected papers from the 22nd International Conference on Historical Linguistics, Naples, 27-31 July 2015, ed. by Claudia Fabrizio \& Michaela Cennamo, 97-114. Amsterdam: John Benjamins.

Bjorvand, Harald. 1972. Zu den altwestnordischen Pluralendungen -ar, -ir und -r bei femininen Substantiva. Norwegian Journal of Linguistics 26. 195-215.

Bobrova, Maria. 2013. Genus ved homofone substantiv [Gender for homophone nouns]. Oslo, Norway: University of Oslo MA thesis.

Busterud, Guro, Terje Lohndal, Yulia Rodina, \& Marit Westergaard. 2019. The loss of feminine gender in Norwegian: A dialect comparison. Journal of Comparative Germanic Linguistics 22. 141-167.

Carstairs-McCarthy, Andrew. 2000. Inflection classes. Morphologie. Ein internationales Handbuch zur Flexion und Wortbildung, ed. by Geert E. Booij, Christian Lehmann, \& Joachim Mugdan, 630-637. Berlin: Walter de Gruyter.

Comrie, Bernard. 1999. Grammatical gender systems: A linguist's assessment. Journal of Psycholinguistic Research 28. 457-466. 
Conzett, Philip, Åse Mette Johansen, \& Hilde Sollid. 2011. Genus og substantivbøying i nordnorske språkkontaktområder [Grammatical gender and declension in language contact areas in North Norway]. Nordand Tidskrift for Andrespråksforskning [Nordand J. Sec. Lang. Res.] 6. 35-71.

Corbett, Greville G. 1991. Gender. Cambridge: Cambridge University Press.

Corbett, Greville G. 2012. Features. Cambridge: Cambridge University Press.

Corbett, Greville G, \& Norman Fraser. 1999. Default genders. Gender in grammar and cognition, ed. by Barbara Unterbeck \& Matti Rissanen, 55-97. Berlin: Mouton de Gruyter.

Dahan, Delphine, Daniel Swingley, Michael K. Tannenhaus, \& James S. Magnusson. 2000. Linguistic gender and spoken-word recognition in French. Journal of Memory and Language 42. 465-480.

Dahl, Östen. 2000. Elementary gender distinctions. Gender in grammar and cognition II: Manifestations of gender, ed. by Barbara Unterbeck, Matti Rissanen, Terttu Nevalainen, \& Mirja Saari, 577-593. Berlin: Mouton de Gruyter.

De Belder, Marijke. 2011. Roots and affixes: Eliminating lexical categories from syntax. Utrecht, The Netherlands: Utrecht University dissertation.

Dussias, Paola E., Jorge R. Valdés Kroff, Rosa E. Guzzardo Tamargo, \& Chip Gerfen. 2013. When gender and looking go hand in hand: Grammatical gender processing in L2 Spanish. Studies in Second Language Acquisition 35. 353-387.

Eichler, Nadine, Veronika Jansen, \& Natascha Müller. 2013. Gender acquisition in bilingual children: French-German, Italian-German, Spanish-German and Italian-French. International Journal of Bilingualism 17. 550-572.

Embick, David. 2010. Localism versus globalism in morphology and phonology. Cambridge, MA: MIT Press.

Embick, David. 2015. The morpheme: A theoretical introduction. Berlin: Mouton de Gruyter.

Embick, David, \& Morris Halle. 2005. On the status of stems in morphological theory. Romance languages and linguistic theory 2003 (Current Issues in Linguistic Theory 270), ed. by Twan Geerts, Ivo von Ginneken, \& Haike Jakobs, 37-62. Amsterdam: John Benjamins.

Embick, David, \& Alec Marantz. 2008. Architecture and blocking. Linguistic Inquiry 29. 1-53.

Enger, Hans-Olav. 2004a. On the relation between gender and declension. Studies in Language 28. 51-82.

Enger, Hans-Olav. 2004b. Tre endringer i det skandinaviske genussystemet i lys av grammatikaliseringsteori. Arkiv för Nordisk Filologi 105. 125-146.

Enger, Hans-Olav. 2009. The role of core and non-core semantic rules in gender assignment. Lingua 119. 1281-1299.

Enger, Hans-Olav. 2011. Gender and contact — a natural morphology 
perspective on Scandinavian examples. Linguistic universals and language variation, ed. by Peter Siemund, 171-203. Berlin: Mouton de Gruyter.

Faarlund, Jan Terje, Svein Lie, \& Kjell Ivar Vannebo. 1997. Norsk referansegrammatikk [A reference grammar of Norwegian]. Oslo: Universitetsforlaget.

Flom, George T. 1903. The gender of English loan-nouns in Norse dialects in America: A contribution to the study of the development of grammatical gender. Journal of English and Germanic Philology 5. 1-31.

Fretheim, Thorstein. 1985. Er bokmålet tre- eller tvekjønnet? Morfologi/ Morphology, ed. by Ernst Håkon Jahr \& Ove Lorentz, 99-102. Oslo: Novus.

Gagliardi, Annie. 2012. The fundamentals of language acquisition. College Park, MD: University of Maryland dissertation.

Graedler, Anne-Line. 1998. Morphological, semantic and functional aspects of English lexical borrowings in Norwegian. Oslo, Norway: University of Oslo dissertation.

Grimstad, Maren Berg, Brita Ramsevik Riksem, Terje Lohndal, \& Tor A. Åfarli. 2018. Lexicalist vs. exoskeletal approaches to language mixing. Linguistic Review 35. 187-218.

Halle, Morris. 1992. The Latvian declension. Yearbook of morphology 1991, ed. by Geert Booij \& Jaap van Marl, 33-47. Dordrecht: Springer.

Halle, Morris, \& Ora Matushansky. 2006. The morphophonology of Russian adjectival inflection. Linguistic Inquiry 37. 351-404.

Harris, James. 1991. The exponence of gender in Spanish. Linguistic Inquiry 22. 27-62.

Harris, James. 1996. The syntax and morphology of class marker suppression in Spanish. Grammatical theory and Romance languages, ed. by Karen Zagona, 99-122. Amsterdam: John Benjamins.

Haspelmath, Martin. 2006. Against markedness (and what to replace it with). Journal of Linguistics 42. 25-70.

Haugen, Einar. 1953. The Norwegian language in America. Philadelphia, PA: University of Philadelphia Press.

Haugen, Einar. 1976. The Scandinavian languages: An introduction to their history. London: Faber.

Haugen, Einar. 1982. Oppdalsmålet. Innføring i et sørtrøndsk fjellbygdmål. Oslo: Tanum-Norli.

Heegård Petersen, Jan, \& Karoline Kühl. 2017. Grammatical gender in Heritage Argentine Danish: Stability and loss. Paper presented at Societas Linguistica Europaea 50, held at University of Zürich, September 10-13, 2017.

Hockett, Charles F. 1958. A course in modern linguistics. New York, NY: MacMillan.

Hopp, Holger. 2016. Learning (not) to predict: Grammatical gender processing in second language acquisition. Second Language Research 32. 277-307. 
Jahr, Ernst Håkon. 1998. Sociolinguistics in historical language contact: The Scandinavian languages and Low German during the Hanseatic period. Language change: Advances in historical sociolinguistics, ed. by Ernst Håkon Jahr, 119-139 Berlin: Mouton de Gruyter.

Jahr, Ernst Håkon. 2001. Historical sociolinguistics: The role of Low German language contact in the Scandinavian typological split of the late Middle Ages. Lingua Posnaniensis 43. 95-104.

Johannessen, Janne Bondi. 2015. The corpus of American Norwegian speech (CANS). Proceedings of the 20th Nordic Conference of Computational Linguistics, NODALIDA 2015, ed. by Beáta Megyesi, 297-300. Linköping: Linköping University Electronic Press.

Johannessen, Janne Bondi, \& Ida Larsson. 2015. Complexity matters: On gender agreement in Heritage Scandinavian. Frontiers in Psychology. https://doi.org/ 10.3389/fpsyg.2015.01842, December 18, 2015.

Johansson, Stig, \& Anne-Line Graedler. 2002. Rocka, hipt og snacksy. Om engelsk i norsk språk og samfunn. Kristiansand: Høyskoleforlaget.

Kihm, Alain. 2005. Noun class, gender and the lexicon-syntax-morphology interfaces: A comparative study of Niger-Congo and Romance languages. The Oxford handbook of comparative syntax, ed. by Guglielmo Cinque \& Richard S. Kayne, 459-512. Oxford: Oxford University Press.

Kramer, Ruth. 2015. The morphosyntax of gender. Oxford: Oxford University Press.

Kramer, Ruth. 2016. The location of gender features in the syntax. Language and Linguistics Compass 10. 661-677.

Kupisch, Tanja, Natascha Müller, \& Katja F. Cantone. 2002. Gender in monolingual and bilingual first language acquisition: Comparing Italian and French. Lingue e Linguaggio 1. 107-147.

Kupisch, Tanja, \& Jason Rothman. 2016. Terminology matters! Why difference is not incompleteness and how early child bilinguals are heritage speakers. International Journal of Bilingualism. https://doi.org/10.1177/ 1367006916654355, June 22, 2016.

Kürschner, Sebastian, \& Damaris Nübling. 2011. The interaction of gender and declension in Germanic languages. Folia Linguistica 45. 355-388.

Lohndal, Terje. 2018. Assignment of Grammatical Gender in American Norwegian. Talk given at ThEGen: Theoretical and Experimental Approaches to Gender held at Humboldt-Universität zu Berlin \& Leibniz-Center General Linguistics, June 14, 2018.

Lohndal, Terje, \& Marit Westergaard. 2016. Grammatical gender in American Norwegian heritage language: Stability or attrition? Frontiers in Psychology. https://doi:10.3389/fpsyg.2016.00344, March 16, 2016. 
Lundquist, Björn, Yulia Rodina, Irina Sekerina, \& Marit Westergaard. 2016. Gender change in Norwegian dialects: Comprehension precedes production. Linguistics Vanguard 2. 69-83.

Lundquist, Björn, \& Øystein A. Vangsnes. 2018. Language separation in bidialectal speakers: Evidence from eye tracking. Frontiers in Psychology. https://doi.10.3389/fpsyg.2018.01394, August 20, 2018.

Lødrup, Helge. 2011. Hvor mange genus er det i Oslo-dialekten? Maal og Minne 2. 120-136.

Marantz, Alec. 1997. No escape from syntax: Don't try morphological analysis in the privacy of your own lexicon. University of Pennsylvania Working Papers in Linguistics 4. 201-225.

Montrul, Silvina. 2008. Incomplete acquisition in bilingualism: Re-examining the age factor. Amsterdam: John Benjamins.

Müller, Natascha. 1999. Gender and number in acquisition. Gender in grammar and cognition, ed. by Barbara Unterbeck \& Matti Rissanen, 351-399. Berlin: Mouton de Gruyter.

Nesse, Agnete. 2005. Boken-han og kua_den. Om endringer i norske genussystem. Maal og Minne, 136-146.

Oltra-Massuet, Maria Isabel. 1999. On the nature of theme vowel: A new approach to Catalan verbal morphology. Cambridge, MA: MIT dissertation.

Oltra-Massuet, Maria Isabel, \& Karlos Arregi. 2005. Stress-by-structure in Spanish. Linguistic Inquiry 36. 43-84.

Opitz, Andreas, \& Thomas Pechmann. 2016. Gender features in German: Evidence for underspecification. The Mental Lexicon 11. 216-241.

Opsahl, Toril. 2009. "Egentlig alle kan bidra!'” En samling sosiolingvistiske studier av strukturelle trekk ved norsk i multietniske ungdomsmiljøer $i$ Oslo ["Actually everybody can contribute!" A collection of sociolinguistic studies of structural properties in the Norwegian spoken by young people in multiethnic communities in Oslo]. Oslo, Norway: University of Oslo dissertation.

Opsahl, Toril. This issue. Dead, but won't lie down? Grammatical gender among Norwegians. 122-146.

Plunkett, Kim, \& Sven Strömquist. 1992. The acquisition of Scandinavian languages. The crosslinguistic study of language acquisition, ed. by Dan I. Slobin, 457-556. Hillsdale, NJ: Lawrence Erlbaum Associates.

Polinsky, Maria. 2008. Gender under incomplete acquisition: Heritage speakers' knowledge of noun categorization. Heritage Language Journal 6. 40-71.

Riksem, Brita Ramsevik. 2018. Language mixing in American Norwegian noun phrases: An exoskeletal analysis of synchronic and diachronic patterns. Trondheim, Norway: NTNU Norwegian University of Science and Technology dissertation. 
Roca, Iggy M. 1989. The organisation of grammatical gender. Transactions of the Philological Society 87. 1-32.

Rodina, Yulia. 2008. Semantics and morphology: The acquisition of grammatical gender in Russian. Tromsø , Norway: University of Tromsø dissertation.

Rodina, Yulia, \& Marit Westergaard. 2012. A cue-based approach to the acquisition of grammatical gender in Russian. Journal of Child Language 39. 1077-1106.

Rodina, Yulia, \& Marit Westergaard. 2013. The acquisition of gender and declension class in a non-transparent system: Monolinguals and bilinguals. Studia Linguistica 67. 47-67.

Rodina, Yulia, \& Marit Westergaard. 2015. Grammatical gender in Norwegian: Language acquisition and language change. Journal of Germanic Linguistics 27. 145-187.

Rodina, Yulia, \& Marit Westergaard. 2017. Grammatical gender in bilingual Norwegian-Russian acquisition: The role of input and transparency. Bilingualism: Language and Cognition 20. 197-214.

Rodina, Yulia, \& Marit Westergaard. Forthcoming. Grammatical gender and declension class in language change: A study of the loss of feminine gender in Norwegian. Journal of Germanic Linguistics.

Rothman, Jason. 2009. Understanding the nature and outcomes of early bilingualism: Romance languages as heritage languages. International Journal of Bilingualism 13. 155-163.

Røyneland, Unn. 2009. Dialects in Norway: Catching up with the rest of Europe? International Journal of the Sociology of Language 196/197. 7-31.

Skjekkeland, Martin. 1997. Dei norske dialektane [The Norwegian dialects]. Kristiansand: Høyskoleforlaget.

Steriopolo, Olga. 2008. Form and function of expressive morphology: A case study of Russian. Vancouver, BC: University of British Columbia dissertation. Svenonius, Peter. 2017. Declension class and the Norwegian definite suffix. The morphosyntax-phonology connection: Locality and directionality at the interface, ed. by Vera Gribanova \& Stephanie S. Shih, 325-359. Oxford: Oxford University Press.

Thornton, Anna M. 2009. Constraining gender assignment rules. Language Sciences 31. 14-32.

Torp, Arne. 2005. The Nordic languages in the 19th century. Nordic languages. An international handbook of the history of the North Germanic languages, vol. 2, ed. by Oscar Bandle, Kurt Braunmüller, \& Ernst Håkon Jahr, 14251436. Berlin: Walter de Gruyter.

Trosterud, Trond. 2001. Genustilordning I norsk er regelstyrt [Assignment of gender in Norwegian is rule-based]. Norsk Lingvistisk Tidsskrift [Norwegian J. Ling.] 19. 29-57. 
Trudgill, Peter. 2013. Gender maintenance and loss in Totenmålet, English, and other major Germanic varieties. In search of Universal Grammar: From Old Norse to Zoque, ed. by Terje Lohndal, 77-107. Amsterdam: John Benjamins.

Urek, Olga, Natalia Mitrofanova, Yulia Rodina, Terje Lohndal, \& Marit Westergaard. 2018. The role of phonological cues in assigning grammatical gender to novel nouns in Norwegian. Poster presented at Gramino, University of Oslo, May 2018.

Vadella, Katherine Lynn. 2016. The morphosyntax of gender and word class in Spanish: Evidence from -(c)ito/a diminutives. Georgetown, Washington DC: Georgetown University dissertation.

Vikør, Lars S. 1995. The Nordic languages: Their status and interrelations. Oslo: Novus Press.

Wechsler, Stephen, \& Larisa Zlatić. 2003. The many faces of agreement. Stanford, CA: CSLI.

Terje Lohndal

NTNU Norwegian University of Science and Technology \&

UiT - The Arctic University of Norway

Department of Language and Literature

N-7491 Trondheim

NORWAY

[terje.lohndal@ntnu.no]

Marit Westergaard

UiT - The Arctic University of Norway \&

NTNU Norwegian University of Science and Technology

Department of Language and Culture

N-9037 Tromsø

NORWAY

[marit.westergaard@uit.no] 